\title{
Mediterranean developed coasts: what future for the foredune restoration?
}

\author{
A. Della Bella ${ }^{1} \cdot$ E. Fantinato ${ }^{1}\left[\right.$ [ F. Scarton ${ }^{2} \cdot$ G. Buffa ${ }^{1}$
}

Received: 8 September 2021 / Revised: 1 October 2021 / Accepted: 4 October 2021 / Published online: 12 October 2021

(c) The Author(s) 2021, corrected publication 2022

\begin{abstract}
The feasibility and efficacy of soft engineering foredune restoration approaches still lack insight from research and monitoring activities, especially in areas where dunes are under persisting human disturbance. We evaluated the efficacy of Mediterranean foredune restoration in dune areas freely accessible to tourists. Foredunes were reconstructed using only sand already available at nearby places and consolidated through the plantation of seedlings of native ecosystem engineer species and foredune focal species. We monitored transplanted and spontaneous seedlings for one year to assess their mortality and growth in relation to the distance from the closest beach access, either formal or informal, as proxy of human disturbance. We also tested whether species differing in their ecology (i.e., affinity to a given habitat) and growth form showed different response to human disturbance. The relationship between seedling mortality and growth and the distance from the closest beach access was tested through Generalized Linear Mixed Models. We found a clear spatial pattern of seedling survival and growth, which decreased as the proximity to the closest beach access increased. Only invasive alien plants and erect leafy species showed to better perform at lower distances from beach accesses. In dune areas with a strong tourist vocation, foredune restoration should be coupled with the implementation of integrated management plans aiming at optimising the relationship between protection and use. Management plans should not only rely on passive conservation measures; rather they should include educational activities to stimulate a pro-environmental behaviour, increase the acceptance of behaviour rules and no entry zones, and actively engage stakeholders in long-term conservation.
\end{abstract}

Keywords Foredune $\cdot$ Human disturbance $\cdot$ Monitoring $\cdot$ Plant traits $\cdot$ Restoration $\cdot$ Sustainability

\section{Introduction}

Coastal dunes are ecologically relevant ecosystems hosting a highly specialised flora and fauna (McLachlan and Brown 2006). They are also crucial for human wellbeing, assuring essential services (Millennium Ecosystem Assessment 2005; Stoll et al. 2015) with substantial socio-economic impacts (Everard et al. 2010). They are structurally important acting as a protecting buffer against storm surge, waves, and wind erosion. Beaches and sand dunes also supply intangible cultural services such as relaxation and recreation (Bessette

E. Fantinato

edy.fantinato@unive.it

1 Department of Environmental Sciences, Informatics and Statistics, University Ca' Foscari of Venice, Via Torino 155, I-30172 Venice, Italy

2 SELC Soc. Coop, Via dell'Elettricità 3/d, 30175 Venice, Italy et al. 2018), cultural/environmental heritage, and educational resource (Nordstrom and Jackson 2012).

However, worldwide increasing human pressures on coastal areas have led to a competition for space between human activities and the coastal environment (Halpern et al. 2008). Nowadays, coastal dunes are facing a worrying decline (Defeo et al. 2009; Del Vecchio et al. 2019; Prisco et al. 2020), which is worsened by climate change and increasingly frequent extreme phenomena (IPCC 2014). Upstream land use changes, dam construction and hard infrastructure building for coastal protection are indirectly affecting remnant dune areas by inducing changes in the hydrodynamics and altering the gradients in sediment transport (Mory and Hamm 1997; Schoonees et al. 2019). Beside this, the replacement of coastal dune ecosystems with tourism-oriented settlements, infrastructures, and facilities are directly resulting in dune loss and degradation and ecological impacts that occur at many temporal and spatial scales (Sperandii et al. 2018). Tourists ban from dune areas can 
support the spontaneous recovery of dune habitats, as the presence and abundance of disturbance-sensitive plant species can increase, so improving sand consolidation (Defeo et al. 2009; Prisco et al. 2021). However, human-mediated activities aimed at protecting and restoring coastal dunes can effectively speed-up the natural recovery process (Elliott et al. 2007; Lithgow et al. 2020). Dune reconstruction represents a feasible and cost-effective nature-based solution (Pontee et al. 2016), which can boost both the ecological conservation of dune habitats and the provision of ecosystem services (Gómez-Pina et al. 2002). Dune reconstruction typically requires sand accumulation through passive sand trapping systems (Gallego-Fernández et al. 2011) or active dune nourishment (Doody 2013). Sand consolidation is than achieved through the plantation of seedlings of ecosystem engineer species, which trap sand grains through their belowground organs leading to dune ridges formation (Bryant et al. 2019; Ciccarelli 2014; Grafals-Soto and Nordstrom 2009; Zanuttigh et al. 2014). Planting seedlings of ecosystem engineer species is highly effective in fostering the recovery of dune functioning and increasing coastal resistance and resilience even in areas where sand supply is scarce (Muñoz-Vallés and Cambrollé 2014). Plants play a crucial role in dune dynamics, strengthening the sediment with root systems, trapping additional windblown sediment, thereby promoting dune growth (Bessette et al. 2018; Sigren et al. 2014). Plants will grow together with the dunes, making dunes natural, sustainable, and cost-effective soft solutions to coastal protection, able to perform functions similar to flood barriers, dissipating storm wave energy and reducing erosion. In addition, in extreme physical environments, plants are essential for biodiversity sustainment since they ameliorate physical stresses thereby creating suitable habitats for organisms that would otherwise be unable to tolerate extreme physical conditions (Borsje et al. 2011). Finally, vegetated dune systems have high aesthetic value, adding amenity and associated economic value to beaches (Overton 2014).

Vegetation planting has been increasingly used in dune restoration projects that use soft engineering stabilization methods to maximize the resistance and resilience of coastal dunes while at the same time restoring and providing natural habitats and coastal ecosystems (Winters et al. 2020). However, soft engineering restoration approaches have not been frequently addressed and still lack insight from research and monitoring activities (D'Alessandro et al. 2020).

One of the biggest challenges in restoration science is to consider disturbance (either natural or human induced) as part of the restored system (Lithgow et al. 2013) and determine whether and how restoration of dunes that includes revegetation is feasible and effective even in areas where restored dunes are under persisting disturbance. This is crucial on Mediterranean developed coasts where coastal dunes and beaches are mostly managed for recreational purposes, raising the need to solve conflicts between socio-economic interests and the protection of these vulnerable ecosystems. Monitoring can provide useful insights to understanding in which conditions of human disturbance plant species of coastal dunes achieve the best results in terms of survival and growth, and to identify possible differences between species or species traits (Bonari et al. 2021a). In a restoration perspective, monitoring allows to determine whether restoration actions are performing as expected and this in turn will allow an efficient allocation of available resources and a reduction of losses. Indeed, while monitoring the efficacy of restoration, most studies addressed attributes of ecosystem integrity (i.e., ecosystem structure; Lithgow et al. 2013) and health (i.e., ecosystem functioning; Lithgow et al. 2013), while the sustainability of coastal dune restoration in the context of human disturbance, namely the efficacy and cost-effectiveness of restoration actions, has generally been neglected.

In this study, we evaluated the sustainability of Mediterranean foredune restoration along the North Adriatic coast (Italy) by monitoring growth and mortality of transplanted and spontaneous seedlings under different levels of human disturbance. Specifically, we addressed the issue by answering the following questions: (1) Are seedling growth and mortality influenced by human disturbance? (2) Do species differing in their ecology (i.e., affinity to a given habitat) and growth form show different response to human disturbance? The use of set of species that have in common structural and functional attributes will enable to overcome taxonomic differences thus allowing ecological comparisons among coastal dunes on a general scale (Vestergaard 2013; Del Vecchio et al. 2018); (3) What recommendations on the sustainability of foredune restoration can be provided?

\section{Material and methods}

\section{Study site}

Our study took place on the western portion of the North Adriatic coast (Italy) comprising the dune system of Capalonga and Vallevecchia (Fig. 1). The mean annual temperature is $14.4{ }^{\circ} \mathrm{C}$, the mean annual precipitation is $1093.3 \mathrm{~mm}$ (https://www.arpa.veneto.it/dati-ambientali/dati-validati/ meteo-idro-ultimi-anni; consulted July 2021), and the tidal range is $70 \mathrm{~cm}$ (Silvestri et al. 2005). The main winds are the Bora and Scirocco; the first one is a NE wind that blows during winter, while the second one is a SE wind that blows during summer (Rossetti and Scotton 2017). The study area consists of Holocenic dunes with a maximum height of $4 \mathrm{~m}$ and a maximum width of $200 \mathrm{~m}$. Dune sediments are mostly 
Fig. 1 Map of the study site and scheme of permanent plot position on the restored foredune. $d$ indicates plot distance from the beach access

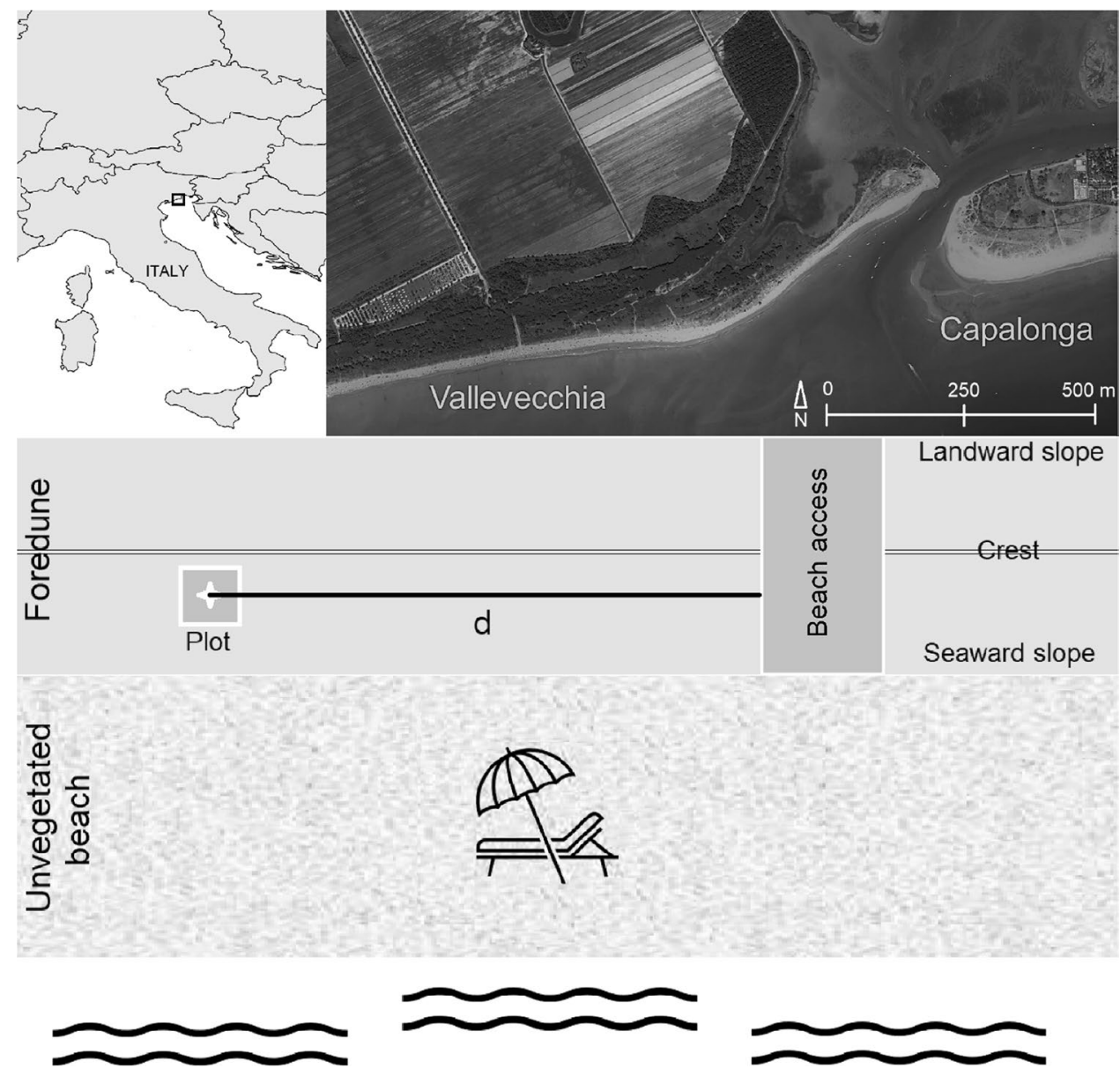

of carbonate origin and in the range of fine sand (Del Vecchio et al. 2016).

Coastal ecosystems are complex and dynamic systems defined by several physical gradients that unfold from the seashore to the inland. In the study area, they mainly consist of three distinct but spatially interconnected habitats: foredunes, transition dunes, and back dunes (Gamper et al. 2008; Sburlino et al. 2008, 2013; Silan et al. 2017). Foredunes are characterised by a species-poor herbaceous vegetation dominated by focal species such as Thinopyrum junceum (L.) Á. Löve (i.e., Elymus farctus (Viv.) Runemark ex Melderis) and Calamagrostis arenaria subsp. arundinacea (Husn.) Banfi, Galasso \& Bartolucci (i.e., Ammophila arenaria subsp. arundinacea (Husn.) H. Lindb.). Until the 1950s, the western portion of the North Adriatic coast was almost entirely fronted by dunes up to $10 \mathrm{~m}$ high (Bezzi and Fontolan 2003; Pignatti 2009). Few of these still survive and the coastline suffers from increasing erosion, reduction in sand supply, alteration of geomorphic processes and heavy human use. In 2019, tourism registered 25 million visitors (https://www.istat.it/it/archivio/178670; consulted July 2021) representing one of the main economic incomes of the region (Bezzi and Fontolan 2003). Massive beach tourism has severely fragmented the continuity of foredunes, raising the need to actively reverse their degradation. Nowadays, the study area is part of a large-scale restoration project carried out in the framework of a European LIFE project (LIFE16 IT/NAT/000589 REDUNE; http://www.liferedune. it/; consulted July 2021). The project aimed at restoring and conserving sandy coastal habitats, including foredunes, and at increasing stakeholder (e.g., citizens, visitors, managers) pro-environmental behaviour and awareness on benefits of the natural environment. To these aims, dune restoration was accompanied by educational activities and site surveillance, which started at the same time of restoration activity implementation (Table 1).

Foredunes restoration took place through a soft-engineering approach, in both study sites, with the aims of reconnecting the dune system by fixing foredune notches caused by human trampling, and revegetating gaps to increase dune stability. At Capalonga, about $2500 \mathrm{~m}^{2}$ of foredunes along $200 \mathrm{~m}$ of littoral strip were reconstructed, using only sand already available at nearby places, where it had been accumulating over the years. The foredunes were built using first a light scraper and then manually modelling the resulting surfaces. Wooden debris, found along the beach, was used to 
Table 1 Description of the principal costs incurred in the foredune restoration carried out in the framework of the European LIFE project LIFE16 IT/NAT/000589 REDUNE (http://www.liferedune.it/; consulted July 2021)

\begin{tabular}{lll}
\hline Expense item & Description & Cost per item \\
\hline Foredune building & $\begin{array}{l}\text { Sand accumulation through light scraper and manual modelling of the resulting surfaces. } \\
\text { Plantation of seedlings of native plants. Allocation of wooden debris at the foredune foot to } \\
\text { protect and stabilise the restored dunes. }\end{array}$ & $\begin{array}{l}\text { Seed sown on suitable substrate and seedling grown in the nursery before plantation in the } \\
\text { restored ecosystems. }\end{array}$ \\
Plant production & $\begin{array}{l}\text { Supply and installation of illustrative wooden noticeboards on coastal dune value and protection } \\
\text { of } 150 \mathrm{~cm} \times 270 \mathrm{~cm} .\end{array}$ & $750.00 € /$ noticeboard \\
Noticeboard installation & $\begin{array}{l}\text { Fences installation along the accesses to the beach. Fences are made up of chestnut poles and } \\
\text { natural jute rope. }\end{array}$ & $50.00 € / \mathrm{m}$ \\
Fences installation & Environmental education activities organised in the project areas. & $250.00 € /$ event \\
Educational activities & &
\end{tabular}

stabilize the foredune foot. At Vallevecchia, a longer strip of foredunes $\left(600 \mathrm{~m}\right.$, for an area of $\left.2100 \mathrm{~m}^{2}\right)$ was built, with the same methodology. A small, off-the-shelf drone was used to survey from the air the reconstruction works at regular intervals at both sites.

Foredune consolidation was achieved through the plantation of seedlings of focal species (i.e., plant species typical of the foredune habitats) produced from local germplasm collected in 2018 (at the nursery of Centro Biodiversità Vegetale e Fuori Foresta; Veneto Agricoltura). The pool of transplanted species was selected based on a reference state defined from a regional-level multiple sites study and literature sources (e.g., Acosta and Ercole 2015). Specifically, the set of species included all functional groups necessary to assure the development and consolidation of the foredunes and with proportions similar to those observed during primary succession in other coastal dunes of the North Adriatic coast. The pool of species used in the foredune restoration included dominant native ecosystem engineer species (i.e., specialised species of the foredune habitats that play a pivotal role in dune dynamics), namely $C$. arenaria subsp. arundinacea, and other subordinate focal species of the foredunes, which increase dune biodiversity and their aesthetic value and play a key role in other ecosystem functions (e.g., in the maintenance of robust pollination networks; Fantinato et al. 2018; Table 2).

Before dune reconstruction, both fencing and boardwalks running perpendicular from the upper beach to the inland were installed to head visitor access to the beach and limit human trampling. Moreover, informal accesses to the beach

Table 2 Summary table of the attributes of the monitored species. Ecological groups and growth forms were derived from Cornelissen et al. (2003) and Del Vecchio et al. (2016)

\begin{tabular}{|c|c|c|c|c|}
\hline Species & $\begin{array}{l}\text { Number of seed- } \\
\text { lings }\end{array}$ & Range of distance (m) & Ecological group & Growth form \\
\hline \multicolumn{5}{|l|}{ Transplanted } \\
\hline $\begin{array}{l}\text { Calamagrostis arenaria (L.) Roth } \\
\text { ssp. arundinacea (Husn.) Banfi, Galasso \& } \\
\text { Bartolucci }\end{array}$ & 55 & $0.12-89.95$ & Focal & Tussock \\
\hline Convolvulus soldanella $\mathrm{L}$. & 26 & $2.50-43.55$ & Focal & Creeping \\
\hline Echinophora spinosa $\mathrm{L}$. & 2 & $1.64-3.46$ & Focal & Erect leafy \\
\hline Eryngium maritimum L. & 34 & $0.13-45.39$ & Focal & Erect leafy \\
\hline Euphorbia paralias L. & 10 & $31.05-44.15$ & Focal & Erect leafy \\
\hline Medicago marina $\mathrm{L}$. & 10 & $29.74-39.41$ & Focal & Creeping \\
\hline \multicolumn{5}{|l|}{ Spontaneous } \\
\hline Ambrosia psilostachya DC. & 41 & $1.23-2.50$ & Alien & Erect leafy \\
\hline Cakile maritima Scop. & 29 & $0.28-9.23$ & Focal & Erect leafy \\
\hline Cynodon dactylon (L.) Pers. & 11 & $1.23-9.23$ & Generalist & Creeping \\
\hline Cyperus capitatus Vand. & 25 & 1.57 & Generalist & Tussock \\
\hline Poacynum venetum (L.) M., L. \& Y.E. A. & 6 & 1.23 & Generalist & Erect leafy \\
\hline Salsola kali $\mathrm{L}$. & 2 & $0.49-2.42$ & Focal & Erect leafy \\
\hline Xanthium italicum Moretti & 55 & $0.49-3.46$ & Alien & Erect leafy \\
\hline
\end{tabular}


have been closed by means of control fencing and heaps of wooden debris. Despite the effort, in Vallevecchia site some informal accesses were re-opened by beach visitors.

\section{Data collection}

Using reconstructed portions of foredunes as strata, we placed 52 permanent plots of $1 \mathrm{~m}$ by $1 \mathrm{~m}$ on the seaward slope using a stratified random sampling design (Random points inside the polygon; Quantum GIS 3.4; Fig. 1). We selected reconstructed portions of foredunes at similar distance from the sea $(54.68 \pm 3.21 \mathrm{~m}$; Mean $\pm \mathrm{SD})$ to explore the influence of human disturbance on seedling mortality and growth under comparable conditions of natural disturbance (e.g., wind intensity, salt spray, sand burial). In each plot we marked all transplanted seedlings, as well as all seedlings spontaneously growing from propagules present in the sand during the monitoring period, to assess their mortality and growth. Moreover, species were grouped according to their habitat affinity (ecological groups) and growth form. To define ecological groups, we firstly distinguished alien plants (based on Celesti-Grapow et al. 2010) from the native ones. Then, we subdivided native species according to their affinity to a given habitat (Buffa et al. 2018; Del Vecchio et al. 2016). Overall, we identified three groups: alien plants, focal species of the foredunes, i.e., plant species typical of the foredune habitats, and generalist species (based on Acosta and Ercole 2015), namely native plant species of coastal dunes that do not show any affinity to a particular habitat. Furthermore, we grouped both alien and native plant species according to their growth form. Growth forms have been proved to be meaningful predictors of plant space occupancy patterns and response to mechanical disturbance (Cole 1995; Lavorel and Garnier 2002; Sun and Liddle 1993). Following Cornelissen et al. (2003), plant species were assigned to the following growth forms: creeping, i.e., reptant herbaceous species with a prostrate growth form (e.g., Convolvulus soldanella L.), erect leafy, i.e., erect plants with leaves concentrated in the middle and/or top part (e.g., Echinophora spinosa L.), and tussock, i.e., many leaves from basal meristem forming tuft (e.g., C. arenaria subsp. arundinacea) (Table 2).

For each seedling we visually estimated the percentage cover and measured different trait attributes according to their growth form. Chosen plant traits were those that best reveal the space occupancy pattern of each growth form (Fantinato et al. 2019; Mason et al. 2013). Specifically, we measured the maximum stolon length for creeping species, the number of leaves for erect leafy species, and the tuft volume for tussocks. We approximated the shape of tussocks to a pyramid trunk; thus, we measured the basal diameters, the upper diameters, and the tuft height to calculate the tuft volume. Overall, we assessed mortality, percentage cover and trait attributes of seedlings every two months, during one year in 2019 (for a total of six surveys).

To describe the spatial pattern of the influence of human disturbance (in the form of trampling) in determining seedling mortality and growth, we recorded the distance of each plot from the closest beach access (m), either formal or informal, by means of a tape measure. Multiple studies (e.g., Buffa et al. 2021; Prisco et al. 2020; Purvis et al. 2015) proved that the distance from beach accesses is a reliable proxy for human disturbance intensity, with intensity increasing with the proximity to beach accesses.

\section{Data analysis}

We tested the relationship between seedling mortality and the distance from the closest beach access $(\log 10$ - transformed) through a Generalized Linear Mixed Model (GLMM; glmr function; package lme4; $\mathrm{R}$ version 3.4.3) including the site identity (i.e., Capalonga and Vallevecchia) as random factor, and using a gamma error-distribution and $\log$ as link function. We quantified seedling mortality as the percentage of dead seedlings per plot recorded at the last monitoring survey (namely after one year from foredune restoration).

We used separate Generalised Linear Mixed Models (GLMMs) to test whether the growth of species grouped according to their habitat affinity (ecological groups) or according to their growth form showed any relationship with the distance from the closest beach access. We used seedling percentage cover when addressing species ecological groups, and values of trait attributes (i.e., maximum stolon length for creeping species, leaf number for erect leafy species, and tuft volume for tussocks) when addressing species growth forms. Each model included the distance from the closest beach access ( $\log 10$ - transformed) as explanatory variable, species cover or trait attribute as dependent variables and site (i.e., Capalonga and Vallevecchia) and species identity as random factors. We used values recorded during each survey as replicates. Cover and trait attributes of dead seedlings were set to zero. We performed GLMMs by using Poisson error-distribution and log link function for the number of leaves and Gamma error-distribution and log link function for all the other variables.

In each GLMM (including both mortality and growth models), we included the quadratic term of the distance from the closest beach access to account for possible nonlinear relationships. We compared linear and quadratic models based on their AIC values, considering the best models as those with the lowest AIC (Akaike's Information Criterion) score. The significance of models was based on likelihood ratio tests (LRT; drop1 function, package stats); moreover, estimates of regression coefficients were standardised. Lastly, we calculated the conditional and marginal 
coefficients of determination $\left(\mathrm{R}_{\mathrm{c}}^{2}\right.$ and $\mathrm{R}_{\mathrm{m}}{ }_{\mathrm{m}}$ ) for the GLMM models (r.squared function; package MuMIn). $\mathrm{R}_{\mathrm{c}}^{2}$ shows the model variance explained by both fixed and random factors, while $R_{m}^{2}$ represents the variance explained by fixed factors alone.

\section{Results}

Overall, we monitored 306 seedlings belonging to 13 plant species (six transplanted and seven spontaneous). Monitored seedlings were recorded between $0.12 \mathrm{~m}$ and $89.95 \mathrm{~m}$ from the closest beach access, with differences in the range of distances occurring among species belonging to different ecological groups (Table 2). While focal species of the foredunes were recorded along the overall range of distances, seedlings of alien and generalist plants occurred relatively close to the beach accesses, with distances ranging from $0.49 \mathrm{~m}$ and $3.46 \mathrm{~m}$ in the case of alien plants (Table 2), and from $1.23 \mathrm{~m}$ to $9.23 \mathrm{~m}$ in the case of generalist species (Table 2). Among seedlings with different growth forms, tussock species were recorded along the overall range of distances, while creeping and erect leafy species occurred between $0.13 \mathrm{~m}$ and $44.15 \mathrm{~m}$, and between $1.23 \mathrm{~m}$ and $43.53 \mathrm{~m}$, respectively (Table 2).

We found a significant negative relationship between seedling mortality and the distance from the closest beach access (Table 3; Fig. 2). In other words, seedling survival increased as the distance from the closest beach access increased, namely human trampling negatively affects seedling survival. In particular, at a distance lower than $1 \mathrm{~m}$ from beach accesses no seedling survived (i.e., seedling mortality

Table 3 Statistics of the relationships between the distance from the closest beach access $(\log 10$ - transformed), seedling mortality $(\%)$, the cover $(\%)$ of plant species grouped according to their habitat affinity, and trait attributes (i.e., maximum stolon length for creeping spe-

\begin{tabular}{|c|c|c|c|c|c|c|c|c|}
\hline Dependent variable & Explanatory variable & $\begin{array}{l}\text { Estimated } \\
\text { coefficient }\end{array}$ & Standard error & $\mathrm{P}$ & AIC & $\chi^{2}$ & $\mathrm{R}^{2} \mathrm{~m}$ & $\mathrm{R}^{2} \mathrm{c}$ \\
\hline Mortality (\%) & $\begin{array}{l}\text { Distance from the closest beach } \\
\text { access (log 10-transformed) }\end{array}$ & -0.014 & 0.004 & 0.018 & 458.82 & 5.524 & 0.086 & 0.086 \\
\hline Focal species cover $(\%)$ & $\begin{array}{l}\text { Distance from the closest beach } \\
\text { access (log 10-transformed) }\end{array}$ & 0.142 & 0.012 & $<0.001$ & 1547.9 & 106.62 & 0.257 & 0.469 \\
\hline Generalist species cover $(\%)$ & $\begin{array}{l}\text { Distance from the closest beach } \\
\text { access (log 10-transformed) }\end{array}$ & 1.061 & 0.281 & $<0.001$ & -194.39 & 15.222 & 0.125 & 0.219 \\
\hline Alien plant cover $(\%)$ & $\begin{array}{l}\text { Distance from the closest beach } \\
\text { access (log 10-transformed })^{2}\end{array}$ & -2.143 & 0.002 & $<0.001$ & -431.49 & 46.217 & 0.055 & 0.062 \\
\hline $\begin{array}{l}\text { Maximum stolon length }(\mathrm{cm}) \text { of } \\
\text { creeping species }\end{array}$ & $\begin{array}{l}\text { Distance from the closest beach } \\
\text { access (log 10-transformed) }\end{array}$ & 0.046 & 0.004 & $<0.001$ & 1375.8 & 11.352 & 0.378 & 0.378 \\
\hline $\begin{array}{l}\text { Number of leaves of erect leafy } \\
\text { species }\end{array}$ & $\begin{array}{l}\text { Distance from the closest beach } \\
\text { access }(\log 10 \text {-transformed })^{2}\end{array}$ & -0.109 & 0.011 & $<0.001$ & 7540.4 & 134.11 & 0.402 & 0.791 \\
\hline $\begin{array}{l}\text { Tuft volume of tussock species } \\
\left(\mathrm{cm}^{2}\right)\end{array}$ & $\begin{array}{l}\text { Distance from the closest beach } \\
\text { access (log 10-transformed) }\end{array}$ & 0.000 & 0.000 & $<0.001$ & 6836.3 & 17.691 & 0.114 & 0.416 \\
\hline
\end{tabular}

was of $100.00 \%$; Fig. 2). Results were consistent also when addressing the relationship between seedling mortality and the distance from the closest beach access differentiating plant species according to their growth form or habitat affinity or whether they had been transplanted or spontaneous (data not shown).

Among species ecological groups, we found a significant positive relationship between the percentage cover of seedlings of focal and generalist species and the distance from the closest beach access (Table 3; Fig. 3). This means that, regardless of the ecological group, all native plant species of coastal dunes were negatively affected by human disturbance. On the other hand, we found a significant humpshaped relationship between the percentage cover of seedlings of alien plants and the distance from the closest beach access (Table 3; Fig. 3).

When considering trait attributes, we found significant positive relationships between the maximum stolon length of creeping species, as well as between the tuft volume of tussock species and the distance from the closest beach access (Table 3; Fig. 3). On the other hand, the number of leaves of erect leafy species showed a significant hump-shaped relationship with the distance from the closest beach access (Table 3; Fig. 3).

\section{Discussion}

Beach-dune systems of Mediterranean developed coasts have been severely damaged by mass tourism, which has negatively affected coastal dune conservation (Defeo et al. 2009; Malavasi et al. 2014; Viciani et al. 2020), integrity

cies $(\mathrm{cm})$, leaf number for erect leafy species, and tuft volume for tussocks $\left(\mathrm{cm}^{2}\right)$ ) of plant species grouped according to their growth form. Statistically significant results $(\mathrm{p}<0.05)$ are highlighted in bold 


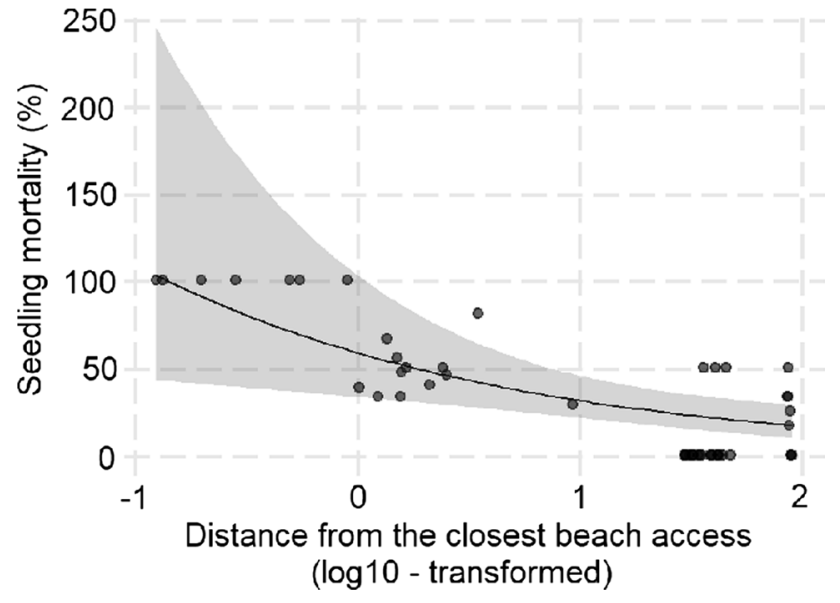

Fig. 2 Relationship between seedling mortality (\%) and the distance from the closest beach access. Line represents the estimate of the Generalised Linear Mixed Models (GLMM). Black points are original data points, while the grey band represents $95 \%$ confidence interval around the regression line (i.e., species composition and community structure) and health (i.e., functional processes). At the local scale, human disturbance in the form of trampling is the most common disturbance in tourism-oriented coasts. Trampling has been proven to lead to the fragmentation and homogenisation of dune habitats (Fantinato 2019; Gallet and Rozé 2001), favour alien plants invasion and the turnover of highly specialised species with generalist more tolerant species (Del Vecchio et al. 2016; Prisco et al. 2021). Furthermore, human trampling mechanically lowers dune crest height, reduces topographic variability, and creates unvegetated gaps and deflation basins which alter wind flows and sand transport rates and directions (Nordstrom et al. 2007).

In this study we showed that human disturbance can also prejudice the sustainability of foredune restoration, namely the long-term efficacy and cost-effectiveness of restoration actions. This is a crucial issue since, as for our study sites, most restoration actions take place in dune areas freely accessible to tourists (Lithgow et al. 2013).
Fig. 3 Relationship between seedling cover (\%) of plant species grouped according to their habitat affinity and values of trait attributes of plant species grouped according to their growth form and the distance from the closest beach access $(\log 10$ - transformed). Lines represent the estimates of the Generalised Linear Mixed Models (GLMM). Black points are original data points, while the grey band represents $95 \%$ confidence interval around the regression line
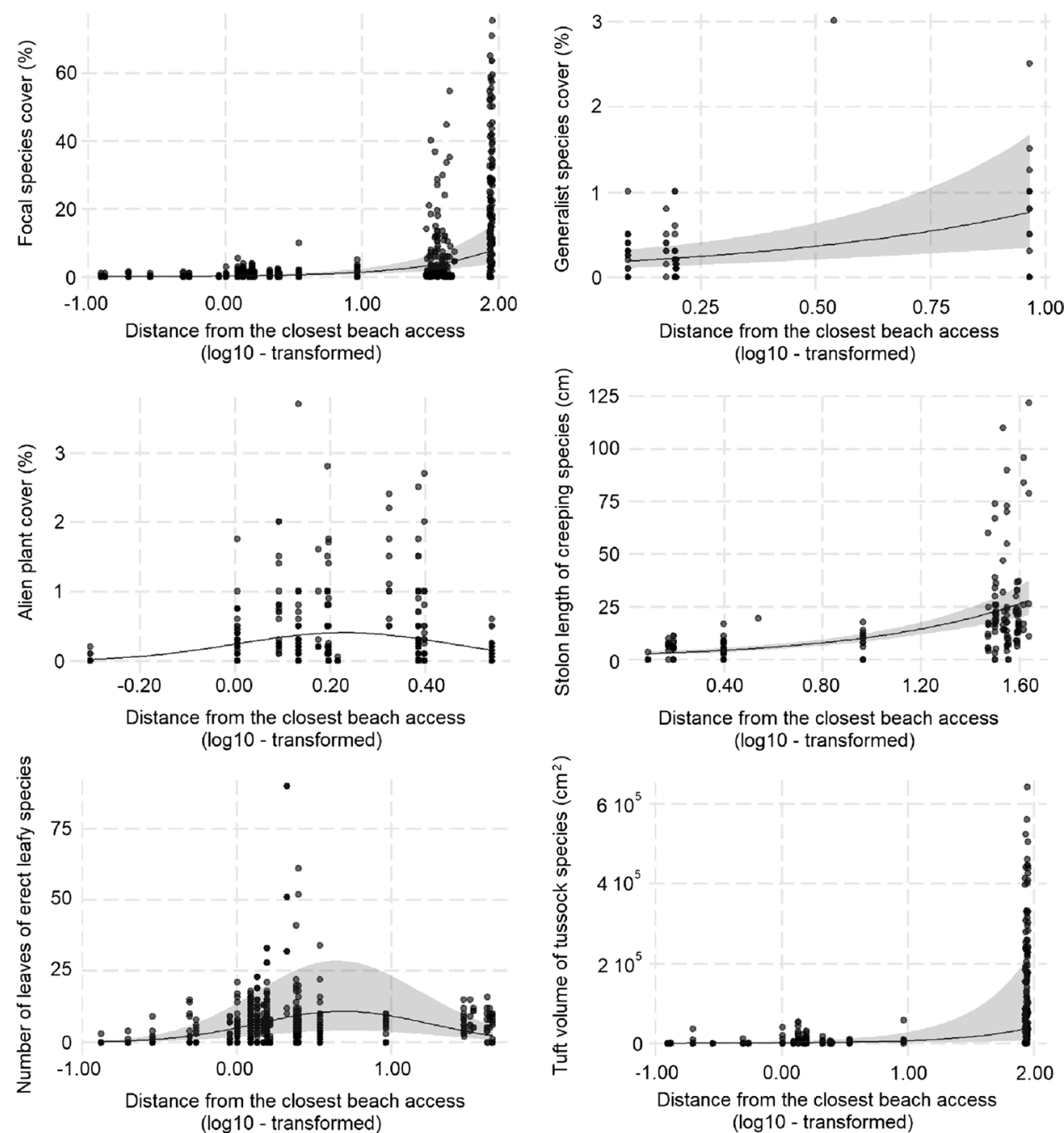
When dealing with plant species with different habitat affinity, we found that focal species of the foredunes were heavily impacted by human disturbance, with both seedling survival and percentage cover decreasing with increasing proximity to the closest beach access. Several studies have shown that human disturbance exerts a detrimental effect on focal species of the foredunes, with the richness and total cover of focal species of both Mediterranean and Atlantic foredunes having experienced a progressive decline as the result of the last decades increasing level of human disturbance (Ciccarelli 2014; Delgado-Fernandez et al. 2019; Prisco et al. 2021). From a restoration perspective, the most crucial issue regards the role of focal species. Foredune species such as $C$. arenaria subsp. arundinacea can also be regarded as ecosystem engineer species since they determine the structure of the community, create suitable ecological conditions for other species, and disproportionally contribute to the ecosystem processes (Ellison et al. 2005; Fantinato et al. 2018; Bonari et al. 2021b). When coastal dunes are artificially (re-)created, they need to be planted with ecosystem engineer plants to boost sand accumulation and further dune growth. In this regard, the loss, or a low growth rate of ecosystem engineer species can possibly determine the failure of the restoration action and ultimately affect the achievement of the integrity of the dune system functionality in enhancing biodiversity, attenuating waves, keeping up with sea level rise, protecting the inland against flooding, and preventing the erosion of the shoreline.

The same pattern of survival and percentage cover held true for generalist species, indicating that native plant species of coastal dunes are negatively affected by human disturbance regardless of their niche breadth.

Interestingly, alien plants showed higher cover in the proximity to the closest beach access. Human disturbance has often been pinpointed as a major driver of alien plant establishment by changing natural disturbance regimes, opening available substrate for invasion, reducing native species cover thereby creating vacant niches, and contributing to the dispersal of alien plant propagules (Buffa et al. 2021; Kowarik 2003; Smith and Kraaij 2020). Indeed, invasive alien plants are often characterised by faster growth and root and leaf turnover rates than native species (Mathakutha et al. 2019), reflecting their capability to rapidly respond to disturbance events. However, and somehow contrary to expectations, also alien plant seedling survival and growth were negatively affected by intense human disturbance, with alien plant cover reaching higher values at intermediate distances from the closest beach access. At increasing distances from the beach access, habitat integrity may limit alien plant cover through biotic resistance of local communities (Elton 1958; Sun et al. 2015), a phenomenon described as the capability of plant communities to withstand alien plant invasions through competition (Parker et al. 2020). Conversely, when potential native perennial competitors are removed by disturbance, alien species are favoured.
Alien species behaviour can be further explained by considering growth forms. The two alien plants we found were erect leafy species and shared the growth form with some focal and generalist species, which showed the same response to human disturbance. Different growth forms indicate differences in plants' resource allocation in response to human disturbance (Fantinato et al. 2019; Liira et al. 2002; Mason et al. 2013). Although human disturbance negatively impacted individual growth regardless of the growth form type, a deviation from the prevailing trend emerged when considering erect leafy species. Seedlings of erect leafy species located nearer to the closest beach access had a higher number of leaves. Several previous studies found a negative correlation between leaf number and trampling intensity, although with differences possibly due to different levels of species resistance to trampling (e.g., Sun and Liddle 1993). In this regard, Cole (1995) found that erect forbs showed a notable variation in their response to trampling that could not be explained by only considering the plant morphology or site characteristics. We speculate that moderate disturbance might induce leaf tissue damage thus fostering the production of new (and more) leaves (the leaf size/number tradeoff; Scott and Aarssen 2012; Whitman and Aarssen 2010). At low distances from the beach access, human disturbance might be too severe to allow leaf production, in accordance with Scott and Aarssen (2012), at high distances we expect the lower number of leaves to be accompanied by a higher size. Moreover, native erect leafy species like Echinophora spinosa L. and Eryngium maritimum L. are characterised by spiny leaves, which can act as a deterrent to people, ultimately fostering their growth also at low distances from the beach access (Šilc et al. 2018). While defensive strategies might allow erect leafy species to withstand moderate disturbance, creeping and tussock species showed to be highly sensitive to disturbance, with values of stolon length and tuft volume significantly decreasing with increasing proximity to the closest beach access. Our results are consistent with previous patterns observed by Cole (1995) and Schlacher et al. (2011), who found that among different growth form types, tussock species were least resistant to human trampling, as tufts can easily be broken (Cole 1995), and that the growth of creeping species like $C$. soldanella was particularly affected by human disturbance (Schlacher et al. 2011).

Growth forms confirmed to be a simple but informative ecological trait, defining species ecological strategies in an extremely synthetic way (Giulio et al. 2021). In this context, our study supports recommendations of Walker et al. (2007), according to which restoration actions should also include a trait-based approach to achieve more effective and sustainable goals. Indeed, we found that both survival and growth of tussock and creeping species increased at increasing distances from the closest beach access, while erect leafy species with spiny leaves had a good performance also at 
lower distance. This suggests that planning the spatial pattern of seedling transplantation according to their traits can contribute to improve restoration efficacy.

After a one year-long monitoring activity, we showed that human disturbance can significantly affect the sustainability of foredune restoration already in the earliest stages, limiting the survival and growth of both transplanted and spontaneous seedlings, ultimately affecting the efficacy of restoration actions and their long-term ecological and economic sustainability. According to Lithgow et al. (2013), the full evaluation of the progress and success of any restoration action needs long-term monitoring, which is essential to determine whether restoration actions are performing as expected and in line with restoration aims. However, short-term monitoring activities may be conceived as an early-alert process that allows to design alternative ways to meet restoration project objectives by adjusting project actions or implementing alternative approaches. In the UN decade of restoration and in the framework of European Green Deal, it is crucial to increase empirical evidence to support the implementation of more informed interventions, inform governance, investment, and policy, and use resources more effectively.

In the present study, the relationship we found between seedling mortality and growth and the distance to the closest beach access turns the spotlight on the importance of planning restoration actions considering human disturbance as part of the restored system. Foredune restoration in dune areas with a strong tourist vocation (such as most Mediterranean coastal dune sites) should be coupled with the implementation of integrated management plans aiming at optimising the relationship between protection and use. Management plans should include a strict control of touristic fluxes through the design of appropriate accesses to the beach, accompanied by information panels. Limiting trampling damage through fences, boardwalks, and betterdesigned accesses to prevent visitors straying from the pathway have been proved to be a highly efficient management measure (Acosta et al. 2013; Muñoz-Vallés and Cambrollé 2014; Prisco et al. 2021). At present, Mediterranean coastal dunes are listed among the most threatened habitats in Europe, and they are in increasingly urgent need of ecological protection and restoration (Sperandii et al. 2021). Reduction or prevention of human impacts on dunes must remain one of the main purposes in coastal dune management.

However, the most important lesson that can be drawn from our study is that only passive conservation measures (e.g., closure of accesses, no entry areas) are not enough to ensure restoration success, and a correct management should include educational activities to stimulate a pro-environmental behaviour and lead visitors to act in a way that benefits the natural environment, or at least does not result in adverse environmental impacts (Kim 2012). In a recent review, Segar et al. (2021) reported that the effectiveness of restoration projects is often constrained by external pressures (e.g., the socio-economic environment), and that the success highly relies on effective communication and policy mechanisms. Although it may be difficult for beach managers to identify the most effective strategies to promote pro-environmental behaviour, educating individuals on the value of coastal dunes is mandatory to influence their behaviour (Dodds and Holmes 2018). According to our results, the long-term sustainability of a restoration project stands on a massive educational activity that however should start long before the implementation of restoration activities. The importance of the environmental education becomes clear when comparing the costs we incurred for educational activities with the costs of foredune restoration and plant production. An early-stage awareness campaign would have increased the acceptance of behaviour rules and no entry areas, actively engaged visitors in dune conservation thereby assuring higher conservation and aesthetic value of newly created dunes, and, most importantly, reducing maintenance costs.

Beach management of Mediterranean developed coasts is typically unbalanced on beaches focusing on accommodating tourism and recreation demands. When this focus is neither controlled nor balanced, degradation of these highly vulnerable systems takes place, compromising both ecosystem integrity and health, and tourism itself.

Acknowledgments we are grateful to Isabelle Cavalli for providing valuable details on foredune restoration actions.

Availability of data and material Data available on request from the authors.

Authors' contributions $\mathrm{GB}$ and $\mathrm{EF}$ formulated the study design. GB, ADB and EF conducted fieldwork. EF analysed the data. GB, ADB, $\mathrm{EF}$ and FS wrote the original copy of the manuscript.

Funding This work was supported by EU in the framework of the European LIFE project LIFE16 IT/NAT/000589 REDUNE. Open access funding provided by Università Ca' Foscari Venezia within the CRUI-CARE Agreement.

\section{Declarations}

Conflicts of interest/competing interests The authors declare no conflict of interests.

Code availability (software application or custom code) Not applicable.

Open Access This article is licensed under a Creative Commons Attribution 4.0 International License, which permits use, sharing, adaptation, distribution and reproduction in any medium or format, as long as you give appropriate credit to the original author(s) and the source, provide a link to the Creative Commons licence, and indicate if changes were made. The images or other third party material in this article are included in the article's Creative Commons licence, unless indicated otherwise in a credit line to the material. If material is not included in the article's Creative Commons licence and your intended use is not permitted by statutory regulation or exceeds the permitted use, you will 
need to obtain permission directly from the copyright holder. To view a copy of this licence, visit http://creativecommons.org/licenses/by/4.0/.

\section{References}

Acosta A, Ercole S (2015) Gli habitat delle coste sabbiose italiane: ecologia e problematiche di conservazione. ISPRA, Serie Rapporti, $215 / 2015$

Acosta ATR, Jucker T, Prisco I, Santoro R (2013) Passive recovery of Mediterranean coastal dunes following limitations to human trampling. In: Martínez M, Gallego-Fernández J, Hesp P (eds) Restoration of coastal dunes. Springer Series on Environmental Management. Springer, Berlin, Heidelberg. https://doi.org/10. 1007/978-3-642-33445-0_12

Bessette SR, Hicks DW, Fierro-Cabo A (2018) Biological assessment of dune restoration in South Texas. Ocean Coast Manag 163:466477. https://doi.org/10.1016/j.ocecoaman.2018.06.019

Bezzi A, Fontolan G (2003) Foredune classification and morphodynamic processes along the Veneto coast (N. Adriatic, Italy). In: E. "Ozhan (Ed.), MEDCOAST '03, MEDCOAST secretariat, Ankara, pp. 1425-1434

Bonari G, Fantinato E, Lazzaro L et al (2021a) Shedding light on typical species: implications for habitat monitoring. Plant Sociol 58:157-166. https://doi.org/10.3897/pls2020581/08

Bonari G, Padullés Cubino J, Sarmati S et al (2021b) Ecosystem state assessment after more than 100 years since planting for dune consolidation. Restor Ecol 29:1-10. https://doi.org/10.1111/rec.13435

Borsje BW, van Wesenbeeck BK, Dekker F et al (2011) How ecological engineering can serve in coastal protection. Ecol Eng 37:113-122. https://doi.org/10.1016/j.ecoleng.2010.11.027

Bryant DB, Anderson Bryant M, Sharp JA et al (2019) The response of vegetated dunes to wave attack. Coast Eng 152:103506. https:// doi.org/10.1016/j.coastaleng.2019.103506

Buffa G, Del Vecchio S, Fantinato E, Milano V (2018) Local versus landscape-scale effects of anthropogenic land-use on forest species richness. Acta Oecol 86:49-56. https://doi.org/10.1016/j. actao.2017.12.002

Buffa G, Gaetan C, Piccoli S et al (2021) Using fine-scale field data modelling for planning the management of invasions of Oenothera stucchii in coastal dune systems. Ecol Indic 125:107564. https:// doi.org/10.1016/j.ecolind.2021.107564

Celesti-Grapow L, Pretto F, Carli E et al (2010) Flora vascolare alloctona e invasiva delle regioni d'Italia. Università La Sapienza, Roma

Ciccarelli D (2014) Mediterranean coastal sand dune vegetation: influence of natural and anthropogenic factors. Environ Manag 54:194-204. https://doi.org/10.1007/s00267-014-0290-2

Cole DN (1995) Experimental trampling of vegetation. 2. Predictors of resistance and resilience. J Appl Ecol 32:215-224. https://doi. org/10.2307/2404430

Cornelissen JHC, Lavorel S, Garnier E et al (2003) A handbook of protocols for standardised and easy measurement of plant functional traits worldwide. Aust J Bot 51:335-380. https://doi.org/ $10.1071 /$ bt02124

D'Alessandro F, Tomasicchio GR, Francone A et al (2020) Coastal sand dune restoration with an eco-friendly technique. Aquat Ecosyst Health Manag 23(4):417-426. https://doi.org/10.1080/14634 988.2020.1811531

Defeo O, McLachlan A, Schoeman DS et al (2009) Threats to sandy beach ecosystems: a review. Estuar Coast Shelf Sci 8:1-12. https:// doi.org/10.1016/j.ecss.2008.09.022

Del Vecchio S, Slaviero A, Fantinato E et al (2016) The use of plant community attributes to detect habitat quality in coastal environments. AoB plants, 8: plw040. doi: https://doi.org/10. 1093/aobpla/plw040

Del Vecchio S, Fantinato E, Janssen JAM et al (2018) Biogeographic variability of coastal perennial grasslands at the European scale. Appl Veg Sci 21:312-321. https://doi.org/10.1111/avsc.12356

Del Vecchio S, Fantinato E, Silan G, Buffa G (2019) Trade-offs between sampling effort and data quality in habitat monitoring. Biodivers Conserv 28:55-73. doi: 10.1007/s10531-018-1636-5)10.1007/ s10531-018-1636-5)

Delgado-Fernandez I, O'Keeffe N, Davidson-Arnott RG (2019) Natural and human controls on dune vegetation cover and disturbance. Sci Total Environ 672:643-656. https://doi.org/10.1016/j.scitotenv. 2019.03.494

Dodds R, Holmes M (2018) Education and certification for beach management: is there a difference between residents versus visitors? Ocean Coast Manag 160:124-132. https://doi.org/10.1016/j.oceco aman.2018.03.043

Doody JP (2013) Sand dune conservation, management and restoration. Springer-Verlag, Heidelberg, Berlin

Elliott M, Burdon D, Hemingway KL et al (2007) Estuarine, coastal and marine ecosystem restoration: confusing management and science-a revision of concepts. Estuar Coast Shelf Sci 74:349-366. https://doi.org/10.1016/j.ecss.2007.05.034

Ellison AM, Bank MS, Clinton BD et al (2005) Loss of foundation species: consequences for the structure and dynamics of forested ecosystems. Front Ecol Environ 3:479-486. https://doi.org/10. 1890/1540-9295(2005)003[0479:LOFSCF]2.0.CO;2

Elton CS (1958) The ecology of invasions by animals and plants. Methuen and Co Ltd, London

Everard M, Jones L, Watts B (2010) Have we neglected the societal importance of sand dunes? An ecosystem services perspective. Aquat Conserv Mar Freshw Ecosyst 20:476-487. https://doi.org/ $10.1002 /$ aqc. 1114

Fantinato E (2019) The impact of (mass) tourism on coastal dune pollination networks. Biol Conserv 236:70-78. https://doi.org/10. 1016/j.biocon.2019.05.037

Fantinato E, Del Vecchio S, Silan G et al (2018) Pollination networks along the sea-inland gradient reveal landscape patterns of keystone plant species. Sci Rep 8:15221. https://doi.org/10.1038/ s41598-018-33652-z

Fantinato E, Sonkoly J, Silan G et al (2019) Pollination and dispersal trait spectra recover faster than the growth form spectrum during spontaneous succession in sandy old-fields. Appl Veg Sci 22:435-443. https://doi.org/10.1111/avsc. 12439

Gallego-Fernández JB, Sánchez IA, Ley C (2011) Restoration of isolated and small coastal sand dunes on the rocky coast of northern Spain. Ecol Eng 37:1822-1832. https://doi.org/10.1016/j.ecole ng.2011.06.017

Gallet S, Rozé F (2001) Resistance of Atlantic heathlands to trampling in Brittany (France): influence of vegetation type, season and weather conditions. Biol Conserv 97:189-198. https://doi. org/10.1016/S0006-3207(00)00111-7

Gamper U, Filesi L, Buffa G et al (2008) Phytocaenotic diversity of the $\mathrm{N}$-Adriatic coastal sand dunes. 1 - the phanerophytic communities. (in Italian). Fitosociologia 45:3-21

Giulio S, Pinna LC, Carboni M et al (2021) Invasion success on European coastal dunes. Plant Sociol 58:29-39. https://doi.org/10. 3897/PLS2021581/02

Grafals-Soto R, Nordstrom K (2009) Sand fences in the coastal zone: intended and unintended effects. Environ Manag 44:420-429. https://doi.org/10.1007/s00267-009-9331-7

Gómez-Pina G, Muñoz-Pérez JJ, Ramírez JL et al (2002) Sand dune management problems and techniques. Spain J Coast Res:325332. https://doi.org/10.2112/1551-5036-36.sp1.325 
Halpern BS, Walbridge S, Selkoe KA et al (2008) A global map of human impact on marine ecosystems. Science 319:948-952. https://doi.org/10.1126/science.1149345

IPCC (2014) Climate change 2014: impacts, adaptation, and vulnerability. Summaries, frequently asked questions, and cross-chapter boxes. A contribution of working group II to the fifth assessment report of the intergovernmental panel on climate change. World Meteorological Organization, Geneva, Switzerland

Kim AK (2012) Determinants of tourist behaviour in coastal environmental protection. Tour Geogr 14:26-49. https://doi.org/10.1080/ 14616688.2011 .597774

Kowarik I (2003) Human agency in biological invasions: secondary releases foster naturalisation and population expansion of alien plant species. Biol Invasions 5:293-312. https://doi.org/10. 1023/B:BINV.0000005574.15074.66

Lavorel S, Garnier E (2002) Predicting changes in community composition and ecosystem functioning from plant traits: revising the holy grail. Funct Ecol 16:545-556. https://doi.org/10.1046/j.13652435.2002.00664.x

Liira J, Zobel K, Mägi R, Molenberghs G (2002) Vertical structure of herbaceous canopies: the importance of plant growth-form and species-specific traits. Plant Ecol 163:123-134. https://doi.org/ 10.1023/A: 1020365402855

Lithgow D, Martínez ML, Gallego-Fernández JB et al (2020) Assessing the current state and restoration needs of the beaches and coastal dunes of Marismas Nacionales, Nayarit, Mexico. Ecol Indic 119:106859. https://doi.org/10.1016/j.ecolind.2020.106859

Lithgow D, Martínez ML, Gallego-Fernández JB et al (2013) Linking restoration ecology with coastal dune restoration. Geomorphology 199:214-224. https://doi.org/10.1016/j.geomorph.2013.05.007

Malavasi M, Santoro R, Cutini M et al (2014) The impact of human pressure on landscape patterns and plant species richness in Mediterranean coastal dunes. Plant Biosyst 29:1541-1550. https://doi. org/10.1080/11263504.2014.913730

Mason NWH, Pipenbaher N, Škornik S et al (2013) Does complementarity in leaf phenology and inclination promote co-existence in a species-rich meadow? Evidence from functional groups. J Veg Sci 24:94-100. https://doi.org/10.1111/j.1654-1103.2012.01451.x

Mathakutha R, Steyn C, le Roux PC et al (2019) Invasive species differ in key functional traits from native and non-invasive alien plant species. J Veg Sci 30:994-1006. https://doi.org/10.1111/jvs.12772

McLachlan A, Brown AC (2006) The ecology of sandy shores. Academic Press, Burlington

Millennium Ecosystem Assessment (2005) Ecosystems and human well-being: biodiversity synthesis. World Resources Institute, Whashington DC

Mory M, Hamm L (1997) Wave height, setup and currents around a detached breakwater submitted to regular or random wave forcing. Coast Eng 31:77-96. https://doi.org/10.1016/S0378-3839(96) 00053-1

Muñoz-Vallés S, Cambrollé J (2014) Successes and failures in the management of coastal dunes of SW Spain: status analysis nine years after management decisions. Ecol Eng 71:415-425. https://doi. org/10.1016/j.ecoleng.2014.07.042

Nordstrom KF, Jackson NL (2012) Foredune restoration in urban settings. In: Martínez ML, Gallego-Fernández JB, Hesp PA (eds) Restoration of coastal dunes. Springer, Berlin

Nordstrom KF, Hartman J, Freestone AL et al (2007) Changes in topography and vegetation near gaps in a protective foredune. Ocean Coast Manag 50:945-959. https://doi.org/10.1016/j.oceco aman.2007.04.004

Overton M (2014) Coastal dunes essential to a resilient coast. ASBPA Shore \& Beach 82:3-12

Parker JD, Devaney JL, Lemoine LP (2020) Biotic resistance to plant invasions. In: Traveset a and Richardson DM (eds) plant invasions: the role of biotic interactions. CABI, pp 177-191. https://doi.org/ $10.1079 / 9781789242171.0001$

Pignatti S (2009) Com'è triste Venezia, soltanto mezzo secolo dopo. Parchi 58:59-70

Pontee N, Narayan S, Beck MW et al (2016) Nature-based solutions: lessons from around the world. Inst civ Eng proc Marit Eng 169:29-36. Doi: 10.1680jmaen.15.00027

Prisco I, Angiolini C, Assini S et al (2020) Conservation status of Italian coastal dune habitats in the light of the 4th monitoring report (92/43/EEC habitats directive). Plant Sociol 57:55-64. https://doi. org/10.3897/PLS2020571/05

Prisco I, Acosta ATR, Stanisci A (2021) A bridge between tourism and nature conservation: boardwalks effects on coastal dune vegetation. J Coast Conserv 25:14. https://doi.org/10.1007/ s11852-021-00809-4

Purvis KG, Gramling JM, Murren CJ (2015) Assessment of beach access paths on dune vegetation: diversity, abundance, and cover. J Coast Res 31:1222-1228. https://doi.org/10.2112/JCOAS TRES-D-13-00198.1

Rossetti V, Scotton M (2017) Topographical, soil, and water determinants of the Vallevecchia coastal dune-marsh system. Ecol Eng 105:32-41. https://doi.org/10.1016/j.ecoleng.2017.04.046

Sburlino G, Buffa G, Filesi L et al (2008) Phytocoenotic originality of the N-Adriatic coastal sand dunes (northern Italy) in the European context: the Stipa veneta-rich communities. Plant Biosyst 142:533-539. https://doi.org/10.1080/11263500802410884

Sburlino G, Buffa G, Filesi L et al (2013) Phytocoenotic diversity of the N-Adriatic coastal sand dunes - the herbaceous communities of the fixed dunes and the vegetation of the interdunal wetlands. Plant Sociol 50:57-77doi: 10.7338/pls2013502/04

Schlacher TA, De Jager R, Nielsen T (2011) Vegetation and ghost crabs in coastal dunes as indicators of putative stressors from tourism. Ecol Indic 11:284-294. https://doi.org/10.1016/j.ecolind.2010. 05.006

Schoonees T, Gijón Mancheño A, Scheres B et al (2019) Hard structures for coastal protection, towards greener designs. Estuar Coasts 42:1709-1729. https://doi.org/10.1007/s12237-019-00551-z

Scott SL, Aarssen LW (2012) Within-species leaf size-number tradeoffs in herbaceous angiosperms. Botany 90:223-235. https://doi. org/10.1139/b11-106

Segar J, Pereira HM, Filgueiras R et al (2021) Expert-based assessment of rewilding indicates progress at site-level, yet challenges for upscaling. Ecography 44:1-10. https://doi.org/10.1111/ecog. 05836

Sigren MJ, Figlu J, Armitage A (2014) Coastal sand dunes and dune vegetation: restoration, erosion, and storm protection. Shore Beach 82:5-12

Silan G, Del Vecchio S, Fantinato E et al (2017) Habitat quality assessment through a multifaceted approach: the case of the habitat 2130* in Italy. Plant Sociol 54:13-22. https://doi.org/10.7338/ pls2017542/02

Šilc U, Kuzmič F, Cakovič D, Steševic D (2018) Beach litter along various sand dune habitats in the southern Adriatic (E Mediterranean). Mar Pollut Bull 128:353-360. https://doi.org/10.1016/j. marpolbul.2018.01.045

Silvestri S, Defina A, Marani M (2005) Tidal regime, salinity and salt marsh plant zonation. Estuar Coast Shelf Sci 62:119-130. https:// doi.org/10.1016/j.ecss.2004.08.010

Smith K, Kraaij T (2020) Trail runners as agents of alien plant introduction into protected areas. J outdoor Recreat Tour 31:100315. https://doi.org/10.1016/j.jort.2020.100315

Sperandii MG, Prisco I, Acosta ATR (2018) Hard times for Italian coast- al dunes: insights from a diachronic analysis based on random plots. Biodivers Conserv 27:633-646. https://doi.org/10. 1007/s10531-017-1454-1 
Sperandii MG, Barták V, Carboni M et al (2021) Getting the measure of the biodiversity crisis in Mediterranean coastal habitats. J Ecol 109:1224-1235. https://doi.org/10.1111/1365-2745.13547

Stoll S, Frenzel M, Burkhard B et al (2015) Assessment of ecosystem integrity and service gradients across Europe using the LTER Europe network. Ecol Model 295:75-87. https://doi.org/10.1016/j. ecolmodel.2014.06.019

Sun D, Liddle MJ (1993) Plant morphological characteristics and resistance to simulated trampling. Environ Manag 17:511-522

Sun Y, Müller-Schärer H, Maron JL et al (2015) Origin matters: diversity affects the performance of alien invasive species but not of native species. Am Nat 185:725-736. https://doi.org/10.1086/ 681251

Vestergaard P (2013) Natural plant diversity development on a manmade dune system. In: Martínez ML, Gallego-Fernández JB, Hesp PA (eds) Restoration of coastal dunes. Springer-Verlag, Berlin Heidelberg, pp 49-66

Viciani D, Vidali M, Gigante D et al (2020) A first checklist of the alien-dominated vegetation in Italy. Plant Sociol 57:29-54. https:// doi.org/10.3897/PLS2020571/04
Walker LR, Walker J, Del Moral R (2007) Forging a new alliance between succession and restoration. In linking restoration and ecological succession. Springer, New York, NY

Winters MA, Leslie B, Sloane EB, Gallien TW (2020) Observations and preliminary vulnerability assessment of a hybrid dune-based living shoreline. J Mar Sci Eng 8:920. https://doi.org/10.3390/ jmse 8110920

Whitman T, Aarssen LW (2010) The leaf size/number trade-off in herbaceous angiosperms. J Plant Ecol 3:49-58. https://doi.org/10. 1093/jpe/rtp018

Zanuttigh B, Simcic D, Bagli S et al (2014) THESEUS decision support system for coastal risk management. Coast Eng 87:218-239

Publisher's note Springer Nature remains neutral with regard to jurisdictional claims in published maps and institutional affiliations. 